\title{
Preliminary Evaluation of Anti-Listerial Bacteriocin-like Peptide Produced by Enterococcus lactis PMD74 Isolated from Ezine Cheese
}

\begin{abstract}
Başar Uymaz Tezel ${ }^{1, a, *}$
${ }^{1}$ Department of Food Technology, Bayramiç Vocational College, Çanakkale Onsekiz, Mart University, 17700 Bayramiç/Çanakkale, Turkey *Corresponding author

\begin{tabular}{|c|c|}
\hline A R T I C L E I N F O & A B S T R A C T \\
\hline $\begin{array}{l}\text { Keywords: } \\
\text { Ezine cheese } \\
\text { Enterococcus lactis } \\
\text { Anti-listerial activity } \\
\text { Bacteriocin-like peptide } \\
\text { Listeria monocytogenes }\end{array}$ & $\begin{array}{l}\text { Enterococcus lactis PMD74 is a novel strain with a notably high antimicrobial activity. The present } \\
\text { study evaluated the anti-listerial effect of a bacteriocin-like peptide (BLIP) produced by E. lactis } \\
\text { PMD74 isolated from Ezine cheese (PDO). The strain was screened for its antimicrobial activity } \\
\text { against } 22 \text { indicator strains using both agar spot and well diffusion methods. We observed that the } \\
\text { neutralized cell-free supernatant (CFS) of E. lactis PMD74 exhibited varying levels of antimicrobial } \\
\text { activity against both closely and distantly related pathogenic strains, with the highest activity } \\
\text { displayed against Listeria monocytogenes strains. Although thermostable and resistant to lysozyme } \\
\text { treatment, BLIP could be completely inactivated by trypsin, proteinase } \mathrm{K} \text {, and } \alpha \text {-chymotrypsin } \\
\text { treatments. BLIP production starts in the early exponential growth phase of E. lactis PMD74 ( } 3 \text { h } \\
\text { incubation, } 400 \text { AU mL }{ }^{-1} \text { ) and reaches its maximal production ( } 6400 \text { AU } \mathrm{mL}^{-1} \text { ) at the end of the } \\
\text { exponential growth phase. Moreover, it is stable in the pH range of } 2.0 \text { to } 7.0 \text {. The treatment of } \\
\text { cultures of L. monocytogenes ATCC } 7644 \text { and Escherichia coli ATCC } 26922 \text { with sterilized CFS } \\
\text { exhibited bactericidal and bacteriostatic effects, respectively. Furthermore, co-inoculation of } L \text {. } \\
\text { monocytogenes ATCC } 7644 \text { and E. lactis PMD74 in skim milk led to complete loss of viability of } \\
\text { L. monocytogenes ATCC } 7644 \text {. These findings suggest that BLIP produced by E. lactis PMD74 } \\
\text { could serve as a promising food preservative agent owing to its bactericidal and bacteriostatic } \\
\text { properties. }\end{array}$ \\
\hline
\end{tabular}
\end{abstract}

buymaz@comu.edu.tr

(iD) https://orcid.org/0000-0002-4156-8861|

This work is licensed under Creative Commons Attribution 4.0 International License

\section{Introduction}

Listeria monocytogenes is a ubiquitous pathogen, the causative agent of listeriosis, which is associated with high mortality, especially in the immunocompromised individuals such as newborns, elderly, and pregnant women (Al-Nabulsi et al., 2015; Şanlıbaba et al., 2018a). According to the 2013 and 2016 reports published by the European Food Safety Authority (EFSA), increasing incidences of listeriosis have been found in the member states (EFSA 2017; Ricci et al., 2018). Although the data from South Africa lack regular documentation, 18.71\% of the patients infected with listeriosis have been reported to die in March 2018 (NICD, 2018). Listeria spp. could be isolated from several different environments, including foods. The ready-to-eat (RTE) products that are consumed without prior cooking are very prone to contamination with L. monocytogenes and act as a reservoir for this pathogen. Despite the implementation of strict food safety standards, the European Union (EU) and United States (US) have adopted a zero-tolerance policy against $L$. monocytogenes in RTE food products (Neria et al., 2019). Being a psychrotrophic microorganism, L. monocytogenes can tolerate and grow in adverse environmental conditions such as refrigeration temperatures, extreme $\mathrm{pH}$ values of 4.39 to 9.40 , high salinity $(40 \% \mathrm{w} / \mathrm{v})$, low water content, and hypoxic conditions (Al-Nabulsi et al., 2015), allowing it to adapt to variable conditions and making it difficult to control it in the food industry. Although contamination by L. monocytogenes during food processing could be avoided using different strategies, failure of hygiene practices and incorrect design of equipment are majorly responsible for its continuous presence in the environment, thereby increasing the risk of cross-contamination (Melero et al., 2019). For effective control of this species, alternative strategies to conventional preservation methods, such as chemical additives, excessive salt to control the growth and/or survival of L. monocytogenes, are imperative. The recent literature cites the use of purified or semi-purified bacteriocins, one of the antimicrobials produced by lactic acid bacteria (LAB) as a starter, protective, or adjunct culture, as the most intensively studied strategies (Yang et 
al., 2012; Fontana et al., 2015; Silva et al., 2016; Hwanhlem et al., 2017). These bacteriocins are harmless to eukaryotic cells and are readily digested by proteolytic enzymes of the digestive system, owing to which these are considered as a good alternative to chemical preservatives (Aspri et al., 2017). Structurally, bacteriocins, synthesized ribosomally by $\mathrm{LAB}$, are small, cationic, amphiphilic (rather hydrophobic) antimicrobial peptides or proteins that vary in their spectrum and mode of activity. These have different molecular structure and molecular mass, thermostability, $\mathrm{pH}$ range of activity, and genetic determinants (Klaenhammer, 1993; Moreno et al., 2006). Since1955 when the first bacteriocin-like substance was isolated from the group D streptococci (Kjems, 1955), a large number of enterocins have been studied to date (Moreno et al., 2006). The anti-listerial activity of bacteriocin was first described by Krämer and Brandis (1975). This phenomenon that can be explained by the close phylogenetic relationship of both genera is well documented today. The primary producers of characterized and purified enterocins are Enterococcal faecalis and Enterococcal faecium strains; these enterocins are grouped into class I, class IIa, class IIc, and class III bacteriocins (Moreno et al., 2006). Moreover, many recent studies have led to the isolation and identification of novel enterococcal strains, excluding E. faecalis, which are widely used in the food industry and suitable if consumed by both human and animals (Sonsa-Ard et al., 2015; Aspri et al., 2017; İspirli et al., 2017; Du et al., 2017; Braïek et al., 2018a). E. lactis, which was first isolated from the Russian sour milk products (Botina and Sukhodolets, 2006) and later in South Africa from fresh sheep milk (Bauer et al., 2009), was described by Morandi et al. (2012) as a novel species belonging to the genus Enterococcus. Braïek et al. (2018a) investigated and described in detail the potential use of bacteriocin produced by $E$. lactis strain, isolated from shrimps, as a natural agent for preserving food. Ezine cheese (PDO) contains biodiversity of spontaneous LAB microbiota and therefore constitutes a rich source for the isolation of novel strains. For example, a novel strain of $E$. lactis, as identified through molecular methods, with notably high antimicrobial activity was isolated from PDO. This strain has been deposited in the NCBI GenBank database under the accession number MK318965-66 as E. lactis PMD74.

The present study evaluated the anti-listerial effects of E. lactis PMD74 and characterized its bacteriocinogenic potential. To the best of our knowledge, this study is the first of its kind to investigate the bacteriocin-producing ability of E. lactis strain in our country. L. monocytogenes is regarded as a major risk factor for food safety; therefore, pioneer studies focusing on the isolation of anti-listerial bacteriocin-producing strains are considered to serve as the database for its control.

\section{Materials and Methods}

\section{Bacterial Strains and Growth Conditions}

E. lactis PMD74 strain was grown overnight in de Man Rogosa Sharpe (MRS; Merck, Germany) medium at $37^{\circ} \mathrm{C}$. Table 1 enlists the source and growth conditions of the indicator strains that were used in the present study. All indicator strains were stored at $-20^{\circ} \mathrm{C}$ in their corresponding suitable broth media supplemented with $20 \%$ glycerol. Working cultures for each strain were prepared by transferring the respective frozen stock culture to the appropriate broth, followed by an overnight incubation to revive the cells.

Table 1 The indicator strains and the antimicrobial activity spectrum of E. lactis PMD74

\begin{tabular}{|c|c|c|c|c|}
\hline \multirow{2}{*}{ Strains } & \multirow{2}{*}{ Source $^{\mathrm{a}}$} & \multirow{2}{*}{$\begin{array}{l}\text { Growth } \\
\text { conditions }\end{array}$} & \multicolumn{2}{|c|}{ Antimicrobial activity $^{\mathrm{c}}$} \\
\hline & & & Agar spot test & Well diffusion \\
\hline Lactobacillus plantarum LMG2003 & NLH & $\mathrm{MRS}, 37^{\circ} \mathrm{C}$ & +++ & $\mathrm{NZ}$ \\
\hline Lactobacillus sake NCDO2714 & NLH & $\mathrm{MRS}, 37^{\circ} \mathrm{C}$ & +++ & +++ \\
\hline Lactococcus lactis SIK83 & NLH & $\mathrm{M} 17,30^{\circ} \mathrm{C}$ & $\mathrm{NZ}$ & NZ \\
\hline Pediococcus pentosaceus FBB611 & NLH & $\mathrm{MRS}, 37^{\circ} \mathrm{C}$ & +++ & ++ \\
\hline Pediococcus pentosaceus $\mathrm{BH} 105$ & AUFF & $\mathrm{MRS}, 37^{\circ} \mathrm{C}$ & $\mathrm{NZ}$ & NZ \\
\hline Bifidobacterium longum CHL28 & NLH & $\mathrm{MRS}, 37^{\circ} \mathrm{C}$ & ++ & NZ \\
\hline Bacillus cereus FM1 & NLH & $\mathrm{LB}, 37^{\circ} \mathrm{C}$ & $\mathrm{NZ}$ & $\mathrm{NZ}$ \\
\hline Listeria monocytogenes ATCC 7644 & AUFF & TSB-YE, $35^{\circ} \mathrm{C}$ & +++ & +++ \\
\hline Listeria monocytogenes L35 & AUDFE & TSB-YE, $35^{\circ} \mathrm{C}$ & +++ & ++ \\
\hline Listeria monocytogenes L38 & AUDFE & TSB-YE, $35^{\circ} \mathrm{C}$ & +++ & ++ \\
\hline Listeria monocytogenes L39 & AUDFE & TSB-YE, $35^{\circ} \mathrm{C}$ & +++ & + \\
\hline Listeria monocytogenes L47 & AUDFE & TSB-YE, $35^{\circ} \mathrm{C}$ & +++ & +++ \\
\hline Listeria monocytogenes L48 & AUDFE & TSB-YE, $35^{\circ} \mathrm{C}$ & +++ & + \\
\hline Listeria monocytogenes L49 & AUDFE & TSB-YE, $35^{\circ} \mathrm{C}$ & +++ & ++ \\
\hline Listeria monocytogenes L74 & AUDFE & TSB-YE, $35^{\circ} \mathrm{C}$ & +++ & +++ \\
\hline Staphylococcus aureus ATCC 6538 & AUFF & $\mathrm{LB}, 37^{\circ} \mathrm{C}$ & +++ & ++ \\
\hline Salmonella enterica serotype Typhimurium SL1344 & AUFF & $\mathrm{LB}, 37^{\circ} \mathrm{C}$ & +++ & NZ \\
\hline Micrococcus luteus NCIMB8166 & AUFF & $\mathrm{LB}, 37^{\circ} \mathrm{C}$ & $\mathrm{NZ}$ & $\mathrm{NZ}$ \\
\hline Enterococcus faecalis LMG2708 & NLH & $\mathrm{BHI}, 37^{\circ} \mathrm{C}$ & +++ & ++ \\
\hline Enterococcus faecalis ATCC 29212 & AUFF & $\mathrm{BHI}, 37^{\circ} \mathrm{C}$ & +++ & ++ \\
\hline Escherichia coli ATCC 26922 & AUFF & $\mathrm{LB}, 37^{\circ} \mathrm{C}$ & +++ & ++ \\
\hline Escherichia coli LMG3083 ETEC & NLH & $\mathrm{LB}, 37^{\circ} \mathrm{C}$ & +++ & ++ \\
\hline
\end{tabular}

${ }^{a}$ NLH: Agricultural University of Norway, AUFF: Faculty of Science, University of Ankara, Turkey, AUDFE: Department of Food Engineering, University of Ankara, Turkey, bMRS: de Man Rogosa Sharpe (Merck, Germany), BHI: Brain Heart Infusion (Merck, Germany), LB: Luria Bertani (Merck, Germany), M17 (Merck, Germany), ${ }^{\mathrm{c} N Z}$ : No inhibition zone, diameter of inhibition zones +: 1-5 mm, ++: 6-10 mm, +++: $\geq 11 \mathrm{~mm}$ 


\section{Evaluation of Antimicrobial Activity}

The E. lactis strain was screened for its antimicrobial activity spectrum using both agar spot test (van Belkum et al., 1989) and well diffusion test (Tagg and Mcgiven, 1971) against the members of the genera Enterococcus, Lactobacillus, Lactococcus, Pediococcus, Bifidobacterium, Listeria, Micrococcus, Bacillus, Staphylococcus, Salmonella, and Escherichia (Table 1).

Approximately, $10^{5}$ to $10^{6} \mathrm{CFU} \mathrm{mL}^{-1}$ of indicator strains were inoculated into BHI, MRS, M17, and LB soft agar and poured over the MRS plates that were pre-seeded with E. lactis PMD74.

To perform the well diffusion assay, the cell-free supernatant (CFS) was collected from an overnight culture of the test strain by centrifugation $(10000 \times \mathrm{g}, 15 \mathrm{~min}$ at $4^{\circ} \mathrm{C}$ ). The $\mathrm{pH}$ of the CFS was adjusted to $6.5 \mathrm{using} 6 \mathrm{mmol}$ $\mathrm{L}^{-1} \mathrm{NaOH}$, and sterilized using a $0.45-\mu \mathrm{m}$ pore size membrane filter (Millipore, France). The sterilized CFS $(100 \mu \mathrm{L})$ was placed into wells made into the medium containing the indicator strains. After $24 \mathrm{~h}$ of incubation at the optimal growth temperature of the respective indicator strains, the plates were examined for inhibition zones. The diameters $(\mathrm{mm})$ of inhibition zones were scored as: NZ (no inhibition zone $),+$ (a clear zone of 1-5 mm), ++ (a clear zone of $6-10 \mathrm{~mm})$, and $+++($ a clear zone of $\geq 11 \mathrm{~mm})$. The proteinous structure of the CFS was determined by its initial degradation by proteolytic enzymes proteinase-K (Thermo Fischer Scientific, United States), trypsin (Sigma Aldrich, Germany), and catalase (Sigma Aldrich, Germany), at a final concentration of $1 \mathrm{mg} \mathrm{mL}^{-1}$, against the indicator strain L. monocytogenes ATCC 7644. The activity was expressed in arbitrary unit per milliliter (AU $\mathrm{mL}^{-1}$ ), with one AU defined as the highest dilution exhibiting a clear zone of inhibition (Daba et al., 1993). The experiment was performed in triplicate.

\section{Partial Characterization of Bacteriocin-Like Peptide}

The effects of enzymes, $\mathrm{pH}$, and heat treatments on the activity and stability of BLIP served as partial characterization (Uymaz et al., 2009). Briefly, the CFS of an overnight culture was obtained as described earlier.

In order to test the effect of enzymes on the activity of BLIP, the CFS was treated with the following enzymes at a final concentration of $1 \mathrm{mg} / \mathrm{mL}$ : trypsin ( $\mathrm{pH} 7.0$; Sigma Aldrich, Germany), $\alpha$-chymotrypsin ( $\mathrm{pH}$ 7.0; Sigma Aldrich), proteinase K (pH 7.0; Thermo Fischer Scientific, United States), pepsin ( $\mathrm{pH} 7.0$; Sigma Aldrich), $\alpha$-amylase (pH 7.0; Sigma Aldrich), lipase (pH 7.0; Sigma Aldrich), catalase (pH 7.0; Sigma Aldrich), and lysozyme (pH 7.0; Sigma Aldrich). The reaction mixtures were incubated at $37^{\circ} \mathrm{C}$ for $2 \mathrm{~h}$, following which the reactions were terminated by heating at $100^{\circ} \mathrm{C}$ for $5 \mathrm{~min}$. The reaction mixtures and untreated supernatant, which was used as a control, were transferred to the wells in the MRS media plates.

In order to determine the effects of $\mathrm{pH}$ on the antimicrobial peptide of the isolate, the $\mathrm{pH}$ of the CSF was adjusted between 2.0 and 11.0 using $6 \mathrm{mmol} \mathrm{L}^{-1} \mathrm{NaOH}$ or $\mathrm{HCl}$. After incubation at $37^{\circ} \mathrm{C}$ for $2 \mathrm{~h}$, the residual activity was tested. The effect of heat on the antimicrobial activity of the peptide was evaluated by heating the CFS for 5,10 , and $15 \mathrm{~min}$ at $80,90,100^{\circ} \mathrm{C}$, respectively, and at $121^{\circ} \mathrm{C}$ for $15 \mathrm{~min}$. In all treatments, the remaining activity was measured by the critical dilution method proposed by Daba et al. (1993) against the indicator strain L. monocytogenes ATCC 7644. The mean values were calculated from three parallel experiments.

\section{Kinetics of Bacteriocin-Like Peptide Production}

The time course of BLIP production was determined according to the method proposed by Ahmadova et al. (2013).

For this purpose, MRS broth was inoculated with an overnight culture $(2 \% \mathrm{v} / \mathrm{v})$ and incubated at $37^{\circ} \mathrm{C}$. At regular intervals of $1 \mathrm{~h}$ for a total of $24 \mathrm{~h}$, the optical density (OD) at $600 \mathrm{~nm}$, Shimadzu, Japan) of the culture and changes in $\mathrm{pH}$ (Sartorius, United States) were determined. The antimicrobial activity of the BLIP in the CFS was also calculated as $\mathrm{AU} \mathrm{mL} \mathrm{mL}^{-1}$ as previously described, every hour for a total of $24 \mathrm{~h}$.

\section{Inhibition of Pathogen}

The effects of BLIP on the growth of pathogens were evaluated both spectrophotometrically (Ahmadova et al., 2013) and through viable cell count in the fermented milk co-inoculated with the pathogen and the isolate (Favaro et al., 2014).

Briefly, the CFS of E. lactis PMD74 was prepared as described earlier. L. monocytogenes ATCC 7644 and E. coli ATCC 26922 were used as Gram-positive and Gramnegative pathogens, respectively. Filter-sterilized CFS (10\%) was added to the cultures of indicator strains during the early exponential phase (3-h-old culture) and incubated at $37^{\circ} \mathrm{C}$. The optical density at $600 \mathrm{~nm}$ was measured at 1 $\mathrm{h}$ intervals for a total of $12 \mathrm{~h}$.

The overnight cultures of L. monocytogenes ATCC 7644 and E. lactis PMD74 were co-inoculated (2\% from each culture, v/v) into skimmed milk $(4 \%, \mathrm{w} / \mathrm{v})$ that had been previously sterilized and cooled to room temperature. The inoculated milk was then incubated at $37^{\circ} \mathrm{C}$ for $24 \mathrm{~h}$ to allow fermentation, followed by storage at $4^{\circ} \mathrm{C}$ for 4 weeks. $L$. monocytogenes ATCC 7644 (2\%, v/v) skimmed milk was used as control. During storage, the co-inoculated fermented milk and control were examined every week for the viability of each bacterium (expressed as $\log \mathrm{CFU} \mathrm{mL}^{-1}$ ) and changes in $\mathrm{pH}$.

\section{Statistical Analysis}

All statistical analyses were performed using the SPSS program (version 17; SPSS Inc., Chicago, IL, United States). Means and standard deviations were calculated and the significant differences were determined using analysis of variance (ANOVA) at the probability level of $\mathrm{P}<0.05$.

\section{Results}

In the present study, we screened the antimicrobial activity spectra of the strain E. lactis PMD74 against different pathogenic and non-pathogenic 22 indicator strains using both agar spot and well diffusion methods. The agar spot assay helped in determining the broad antimicrobial activity spectrum, including the Gramnegative bacteria, as presented in Table $1(\mathrm{P}<0.05)$. We observed that the neutralized CFS of E. lactis PMD74 exhibited antimicrobial activity against both closely related and unrelated Gram-positive bacteria. The treatment of neutralized CFS isolated from E. lactis PMD74 with 
proteinase-K and trypsin resulted in a complete loss of its antimicrobial activity against E. faecalis ATCC 29212. However, no alteration in the antimicrobial activity was observed with catalase treatment (data not shown). The antimicrobial activity of BLIP was calculated to be 6400 $\mathrm{AU} \mathrm{mL}^{-1}$.

The activity of BLIP was completely inactivated by trypsin, proteinase $\mathrm{K}$, and $\alpha$-chymotrypsin treatments. Although the BLIP peptide displayed resistance to lysozyme treatment, we observed a $50 \%$ reduction in its antimicrobial activity after treatment with other enzymes. The activity was unaffected by heat treatment at $80^{\circ} \mathrm{C}$ for 5 and $10 \mathrm{~min}$; however, it decreased to $50 \%$ after treatment at 90 and $100^{\circ} \mathrm{C}$. Interestingly, heat treatment at $121^{\circ} \mathrm{C}$ for 15 min could not completely inactivate the peptide. With respect to the effect of $\mathrm{pH}$, the antimicrobial activity of BLIP was found to remain stable at $\mathrm{pH} 2.0$ to 7.0 ; however, increasing the $\mathrm{pH}$ level to 8.0 led to the variable percentage of activity loss $(\mathrm{P}<0.05)$ (Table 2$)$.

Table 2 Effect of enzymes, temperature, and $\mathrm{pH}$ treatment on bacteriocin activity

\begin{tabular}{|c|c|}
\hline $\begin{array}{rr}\text { Application } \\
\end{array}$ & Activity $\left(\mathrm{AU} \mathrm{mL} \mathrm{mL}^{-1}\right)$ E. lactis PMD74 \\
\hline Control & 6400 \\
\hline Enzymes & \\
\hline Trypsin & - \\
\hline$\alpha$-chymotrypsin & - \\
\hline Proteinase K & - \\
\hline Pepsin & 3200 \\
\hline$\alpha$-amylase & 3200 \\
\hline Lipase & 3200 \\
\hline Catalase & 3200 \\
\hline Lysozyme & 6400 \\
\hline Temperature & \\
\hline $80^{\circ} \mathrm{C} / 5 \mathrm{~min}$ & 6400 \\
\hline $80^{\circ} \mathrm{C} / 10 \mathrm{~min}$ & 6400 \\
\hline $80^{\circ} \mathrm{C} / 15 \mathrm{~min}$ & 3200 \\
\hline $90^{\circ} \mathrm{C} / 5 \mathrm{~min}$ & 3200 \\
\hline $90^{\circ} \mathrm{C} / 10 \mathrm{~min}$ & 3200 \\
\hline $90^{\circ} \mathrm{C} / 15 \mathrm{~min}$ & 3200 \\
\hline $100^{\circ} \mathrm{C} / 5 \mathrm{~min}$ & 3200 \\
\hline $100^{\circ} \mathrm{C} / 10 \mathrm{~min}$ & 3200 \\
\hline $100^{\circ} \mathrm{C} / 15 \mathrm{~min}$ & 1600 \\
\hline $121^{\circ} \mathrm{C} / 15 \mathrm{~min}$ & 800 \\
\hline $\mathrm{pH}$ & \\
\hline 2 & 6400 \\
\hline 3 & 6400 \\
\hline 4 & 6400 \\
\hline 5 & 6400 \\
\hline 6 & 6400 \\
\hline 7 & 6400 \\
\hline 8 & 3200 \\
\hline 9 & 3200 \\
\hline 10 & 1600 \\
\hline 11 & 1600 \\
\hline
\end{tabular}

Figure 1 shows the kinetics of BLIP production and growth of E. lactis PMD74. It was observed that the BLIP production started in the early exponential growth phase (3

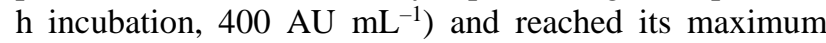
production $\left(6400 \mathrm{AU} \mathrm{mL} \mathrm{m}^{-1}\right)$ at the end of this phase $(8 \mathrm{~h}$ of incubation). During the stationary growth phase of the strain, $50 \%$ to $75 \%$ decrease in the production of BLIP was recorded. According to these results, E. lactis PMD74 strain was determined as a low acidifier owing to the $\mathrm{pH}$ of the earlier phase of growth ( $5 \mathrm{~h}$ incubation) to be below 5.0 , after which there was negligible change in the $\mathrm{pH}$ during next $24 \mathrm{~h}$ of incubation (data not shown).

Figure $2 \mathrm{a}$ and $2 \mathrm{~b}$ summarize the inhibitory effects of BLIP produced by E. lactis PMD74 on pathogens. The treatment of cell cultures of L. monocytogenes ATCC 7644 and E. coli ATCC 26922 with sterilized CFS in the early exponential growth phase $(3 \mathrm{~h})$ inhibited their growth, which is attributed to the maximum production of BLIP during this phase. The observed decrease in the OD immediately after the addition of CFS (Figure 2a) could be explained by the lysis of cells of $L$. monocytogenes ATCC 7644. On the other hand, cell lysis was recorded after $8 \mathrm{~h}$ of treatment in the case of E. coli ATCC 26922. Coinoculation of skim milk with L. monocytogenes ATCC 7644 and E. lactis PMD74 resulted in complete loss of viability of L. monocytogenes ATCC 7644 after fermentation. However, the controlled growth of $L$. monocytogenes ATCC 7644 did not affect the viability during the storage period. On the other hand, viable counts of the strain E. lactis PMD74 remained almost consistent (Figure 3). 


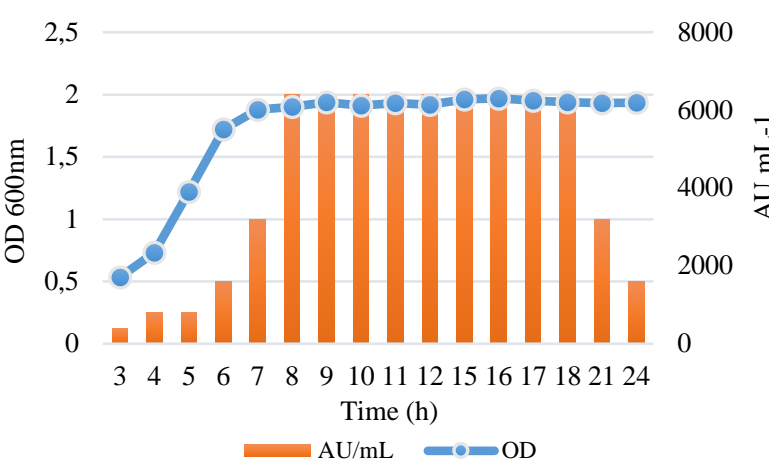

Figure 1 Time course of bacteriocin-like peptide production by E. lactis PMD74

a

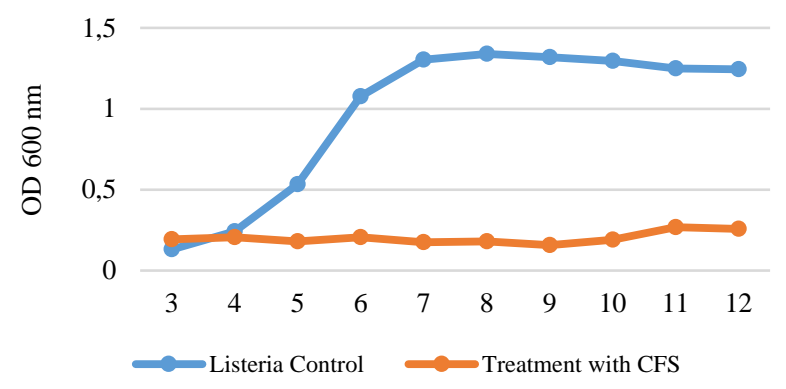

b

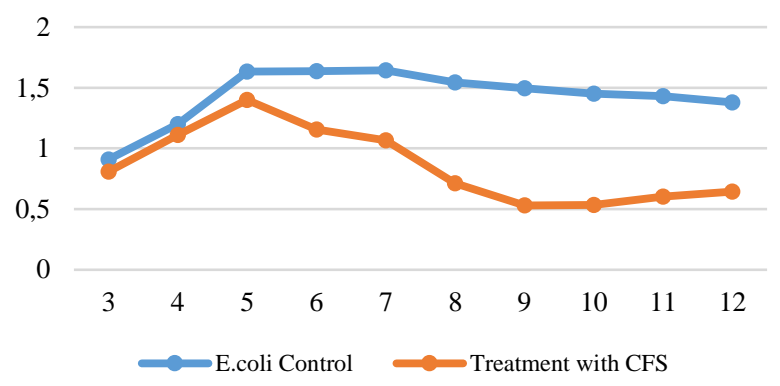

Figure 2 Effect of CFS of E. lactis PMD74 on the growth of L. monocytogenes ATCC 7644 (a) and Escherichia coli ATCC 26922 (b)

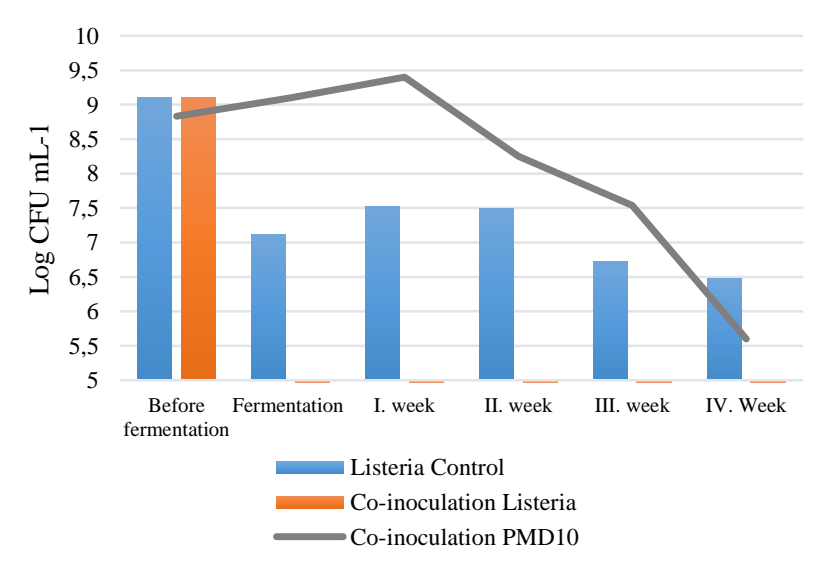

Figure 3 The viability of L. monocytogenes ATCC 7644 and E. lactis PMD74 in co-inoculated skim milk during storage

\section{Discussion}

The results of the present study report E. lactis PMD74mediated inhibition of growth of closely related Grampositive bacteria and Gram-negative pathogenic strains to varying levels. This inhibitory activity is associated with the production of the bacteriocin like peptide BLIP by $E$. lactis PMD74. Similar spectra of inhibitory activity by different enterococcal strains have been reported previously by other authors as well (Ahmadova et al., 2013; İspirli et al., 2017; Braïek et al., 2018a), suggesting that the present study was noteworthy and significant in documenting the antimicrobial activity of E. lactis PMD74 against all tested $L$. monocytogenes strains. The highest activity of the neutralized CFS was detected against $L$. monocytogenes ATCC 7644, L. monocytogenes 47 , and $L$. monocytogenes 74 . Listeriosis, caused by $L$. monocytogenes, is one of the most important bacterial infections worldwide, with several studies reporting its increasing occurrence (EFSA 2017, Ricci et al., 2018). Although studies on the antimicrobial activity of E. lactis PMD74 are sparse in our country, Şanlibaba and colleagues demonstrated the high prevalence of $L$. monocytogenes in RTE foods (2018a) and dairy products (2018b, 2018c). To determine the anti-listerial activity of E. lactis PMD74, L. monocytogenes strains isolated from RTE foods were selected as indicator strains. The results of the present study were observed to be consistent with those reported in the study by Braïek et al. (2018b; 2018c), who described the antimicrobial effects of E. lactis against Enterococcus spp. and Listeria spp. The observed high anti-listerial effect of the tested strain is in line with the studies reported previously by two different groups (Belgacem et al., 2010; Ahmadova et al., 2013). However, the activity of $E$. lactis PMD74 against $L$. monocytogenes in the present study was reported to be considerably higher than that reported in the study conducted by Braïek et al. (2018b; 2018c). The loss of antimicrobial activity of the neutralized CFS upon treatment with proteinase- $K$ and trypsin indicated the proteinaceous nature of the antimicrobial compound. The antimicrobial activity of $E$. lactis PMD74, which was found to be higher than that reported for E. faecium by Sonsa-Ard et al. (2015) and Ahmadova et al. (2013) (1828 $\mathrm{AU} \mathrm{mL}^{-1}$ and $3200 \mathrm{AU}^{-}$ ${ }^{1}$, respectively), was estimated to be $6400 \mathrm{AU} \mathrm{mL}^{-1}$. This is more than that estimated by Braïek et al. (2018a) who recorded the maximum activity for $E$. lactis strains to be $1400 \mathrm{AU} \mathrm{mL}^{-1}$.

Although treatment of CFS with proteolytic enzymes led to a total loss of its activity, treatment with other enzymes such as catalase, lipase, lysozyme, and $\alpha$-amylase did not have any effect. Insensitivity to catalase could be explained by the fact that the antimicrobial activity of $E$. lactis PMD74 is not related to the production of $\mathrm{H}_{2} \mathrm{O}_{2}$ (Ahmadova, 2013). The inability of lipase and lysozyme to degrade BLIP is related to the absence of a requirement of a lipid moiety in the peptide. Retention of antimicrobial activity upon treatment with lipase and lysozyme also indicated BLIP to be pure protein molecule rather than a conjugated one (Osmanağaoğlu et al., 2007; Rivas et al., 2012). Heating the CFS at 90 and $100^{\circ} \mathrm{C}$ has been reported to cause a $50 \%$ decrease in the activity. Regardless of the antimicrobial decrease observed after heating at $121^{\circ} \mathrm{C}$, the 
BLIP was regarded as heat stable since its activity was not completely lost. Thermostability has been reported to be a common property of bacteriocins produced by Enterococcus spp. Moreover, it is a crucial characteristic of a bacteriocin to be used as a food preservative, since many food-processing procedures involve a heating step (Aspri et al., 2017). The thermostability displayed by the enterocin-like substance tested was compatible with the results obtained from studies on other bacteriocinogenic $E$. faecium strains (Belgacem et al., 2010; Rivas et al., 2012; Ahmadova et al., 2013). Furthermore, the observed wide $\mathrm{pH}$ range stability of BLIP produced by E. lactis PMD74 was similar to that reported in the previous studies on bacteriocins of E. faecium (Ahmadova et al., 2013; Favaro et al., 2014; Aspri et al., 2017). pH stability is another trait that enhances the potential of bacteriocin as a natural preservative for foods.

The BLIP could be regarded as a secondary metabolite owing to its highest production in the in the stationary phase. This finding is compatible with that reported by a previous study on bacteriocins produced by E. faecium (Favaro et al., 2014).

The BLIP produced by E. lactis PMD74 was shown to exert certain remarkable effects on the growth of pathogens. The results of the present study indicated the inhibition of cell growth to be dependent on the indicator strain used. For instance, BLIP caused lysis of cells of $L$. monocytogenes ATCC 7644, which could be explained by its bactericidal effect; however, it exhibited a bacteriostatic action on the E. coli strain ATCC 26922. These results are in line with those reported by Ahmadova et al. (2013). The ability to survive and inhibit the pathogen in the acidic conditions of fermented milk for four weeks is also suggestive of its potential use in food systems as a biopreservative.

The genus Enterococcus is usually not considered to be a "generally recognized as safe" (GRAS). Enterococci are also known to be opportunistic pathogens and are associated with developing nosocomial infections, indicating their role as a food preservative to be controversial (Franz et al., 2011; Bigwood et al., 2012). However, virulence factors responsible for the pathogenicity are strain specific, with their expression depending on several environmental factors (Carlos et al., 2010). Therefore, the potential of some of these strains to exert beneficial effects always exist.

\section{Conclusion}

The results of the present work indicate that BLIP produced by the newly isolated strain E. lactis PMD74 could serve as a potential bio-preservative against foodborne pathogens to increase food safety. The remarkably high inhibitory activity of BLIP recorded against Listeria spp. will be a pioneer finding for future studies on the control of L. monocytogenes that has emerged as a major health concern worldwide, especially in foods. The present study could be considered as a preliminary study to identify BLIP as an enterocin produced by E. lactis PMD74. To conclude, with respect to food safety, more studies are warranted to determine the structural genes coding for the known enterocins. The strain also should be evaluated respect of safety.

\section{Acknowledgement}

The author expresses her gratitude to Yurtsev Uymaz, Erhan Tezel, and Gülcan Çiftçi for their kind helps. The author declares that they have no conflict of interest.

\section{References}

Ahmadova A, Todorov SV, Choiset Y, Rabesona H, Zadi AM, Kuliyev A, Franco BDGDM, Chobert JM, Haertlé T. 2013. Evaluation of antimicrobial activity, probiotic properties and safety of wild strain Enterococcus faecium AQ71 isolated from Azerbaijani Motal cheese. Food Control, 30: 631-641. DOI:10.1016/j.foodcont.2012.08.009.

Al-Nabulsi AA, Osaili TM, Shaker RR, Olaimat AN, Jaradat ZW, Elabedeen NAZ, Holley RA. 2015. Effects of osmotic pressure, acid, or cold stresses on antibiotic susceptibility of Listeria monocytogenes. Food Microbiol., 46: 154-160. DOI: 10.1016/j.fm.2014.07.015.

Aspri M, O’Connor PM, Field D, Cotter PD, Ross P, Hill C, Papademas P. 2017. Application of bacteriocin-producing Enterococcus faecium isolated from donkey milk, in the biocontrol of Listeria monocytogenes in fresh whey cheese. Int. Dairy J., 73: 1-9. DOI: 10.1016/j.idairyj.2017.04.008.

Bauer R, Bekker JP, van Wyk N, du Toit C, Dicks LMT, Kossmann J. 2009. Exopolysaccharide production by lactosehydrolyzing bacteria isolated from traditionally fermented milk. Int J Food Microbio., 131:260-264. DOI:10.1016/ j.ijfoodmicro.2009.02.020.

Belgacem Z, Abriouel H, Ben Omar N, Lucas R, MartínezCanamero M, Gálvez A, Manai M. 2010. Antimicrobial activity, safety aspects, and some technological properties of bacteriocinogenic Enterococcus faecium from artisanal Tunisian fermented meat. Food Control, 21: 462-470. DOI: 10.1016/j.foodcont.2009.07.007.

Bigwood T, Hudson JA, Cooney J, McIntyre L, Billington C, Heinemann JA, Wall F. 2012. Inhibition of Listeria monocytogenes by Enterococcus mundtii isolated from soil. Food Microbiol., 32: 354-360. DOI: 10.1016/ j.fm.2012.07.015.

Botina SG, Sukhodolets VV. 2006. Speciation in bacteria: comparison of the 16S rRNA 208 gene for closely related Enterococcus species. Russ J Genet., 42: 247-251. DOI: $10.1134 / \mathrm{S} 1022795406030033$.

Braiek OB, Cremonesi P, Morandi S, Smaoui S, Hani K, Ghrairi T. 2018a. Safety characterisation and inhibition of fungi and bacteria by a novel multiple enterocin-producing Enterococcus lactis 4CP3 strain. Microb Pathog., 118: 32-38. DOI: 10.1016/j.micpath.2018.03.005.

Braïek OB, Morandi S, Cremonesi P, Smaoui S, Hani K, Ghrairi T. 2018b. Safety, potential biotechnological and probiotic properties of bacteriocinogenic Enterococcus lactis strains isolated from raw shrimps. Microb Pathog., 117: 109-117. DOI: 10.1016/j.micpath.2018.02.021.

Braïek OB, Morandi S, Cremonesi P, Smaoui S, Hani K, Ghrairi T. 2018c. Biotechnological potential, probiotic and safety properties of newly isolated enterocin-producing Enterococcus lactis strains. LWT- Food Sci Technol., 92: 361-370. DOI: 10.1016/j.lwt.2018.02.045.

Carlos A, Semedo-Lemsaddek T, Barreto-Crespo M, Tenreiro R. 2010. Transcriptional analysis of virulence-related genes in enterococci from distinct origins. J Appl Microbiol., 108: 1563-1575. DOI: 10.1111/j.1365-2672.2009.04551.x.

Daba H, Lacroix C, Huang J, Simard RE. 1993. Influence of growth conditions on production and activity of a bacteriocin produced by Leuconostoc mesenteroides. Appl Environ Microbiol., 57: 3450-3455. 
Du L, Liu F, Zhao P, Zhao T, Doyle MP. 2017. Characterization of Enterococcus durans 152 bacteriocins and their inhibition of Listeria monocytogenes in ham. Food Microbiol., 68: 97103. DOI: $10.1016 /$ j.fm.2017.07.002.

EFSA (European Food Safety Authority) and ECDC (European Centre for Disease Prevention and Control), 2017. The European Union summary report on trends and sources of zoonoses, zoonotic agents and food-borne outbreaks in 2016. EFSA J. 15, 5077. DOI: 10.2903/j.efsa.2017.5077.

Favaro L, Basaglia M, Casella S, Hue I, Dousset X, de Melo Franco BDG, Todorov SD. 2014. Bacteriocinogenic potential and safety evaluation of non-starter Enterococcus faecium strains isolated from homemade white brine cheese. Food Microbiol., 38: 228-239. DOI: 10.1016/j.fm.2013.09.008

Fontana C, Cocconcelli PS, Vignolo G, Saavedra L. 2015. Occurrence of antilisterial structural bacteriocins genes in meat borne lactic acid bacteria. Food Control, 47: 53-59. DOI:10.1016/j.foodcont.2014.06.021.

Franz CMAP, Huch M, Abriouel H, Holzapfel W, Gálvez A. 2011. Enterococci as probiotics and their implications in food safety. Int J Food Microbiol., 151: 125-140. DOI: 10.1016/j.ijfoodmicro.2011.08.014.

Hwanhlem N, Ivanova T, Biscola V, Choiset Y, Haertlé T. 2017. Bacteriocin producing Enterococcus faecalis isolated from chicken gastrointestinal tract originating from Phitsanulok, Thailand: Isolation, screening, safety evaluation and probiotic properties. Food Control, 78:187-195. DOI:10.1016 /j.foodcont.2017.02.060

İspirli H, Demirbaş F, Dertli E. 2017. Characterization of functional properties of Enterococcus spp. isolated from Turkish white cheese. LWT- Food Sci. Technol., 75: 358365. DOI: 10.1016/j.lwt.2016.09.010.

Kjems E. 1955. Studies on streptococcal bacteriophages: I. Techniques for isolating phage producing strains. Patholo Microbiol Scand., 36: 433-440.

Klaenhammer TR. 1993. Genetics of bacteriocins produced by lactic acid bacteria. FEMS Microbiol. Rev., 12: 39-86. DOI: 10.1111/j.1574-6976.1993.tb00012.x.

Krämer J, Brandis, H. 1975. Mode of action of two Streptococcus faecium bacteriocins. Antimicrob Agents Chemother., 7: 117-120.

Melero B, Stessl B, Manso B, Wagner M, Esteban-Carbonero ÓJ, Hernández M, Rovira J, Rodriguez-Lázaro D. 2019. Listeria monocytogenes colonization in a newly established dairy processing facility. Int. J. Food Microbiol., 289: 64-71. DOI:10.1016/j.ijfoodmicro.2018.09.003.

Morandi S, Cremonesi P, Povolo M, Brasca M. 2012. Enterococcus lactis sp. nov., from Italian raw milk cheeses. Inter J Syst Evol Microbiol., 62: 1992-1996 DOI: 10.1099/ijs.0.030825-0.

Moreno MRF, Sarantinopoulos P, Tsakalidou E, De Vuyst L. 2006. The role and application of enterococci in food and health. Int. J. Food Microbiol., 106: 1-24. DOI: 10.1016/ j.ijfoodmicro.2005.06.026.

Neria D, Antocia S, Iannettia L, Ciorbab AB, D'Aurelioa R, Del Mattoa I, Di Leonardoa M, Giovanninia A, Prencipea VA, Pomilioa F, Santarellia GA, Miglioratia G. 2019. EU and US control measures on Listeria monocytogenes and Salmonella spp. in certain ready-to-eat meat products: An equivalence study. Food Control, 96: 98-103. DOI: 10.1016/ j.foodcont.2018.09.001.
NICD, Situation Update on Listeriosis Outbreak, South Africa, 2018, http://www.nicd.ac.za/wp-content/uploads/2018/03 /listeriasitrep-13mar2018_finalapproved.pdf.

Osmanağaoğlu O. 2007. Detection and characterization of Leucocin OZ, a new anti-listerial bacteriocin produced by Leuconostoc carnosum with a broad spectrum of activity. Food Control, 18: 118-123. DOI: 10.1016/j.foodcont.2005.08.015.

Ricci A, Allende A, Bolton D, Chemaly M, Davies R, Escámez PSF, Girones R, Herman L, Koutsoumanis K, Nørrung B, Robertson L, Ru G, Sanaa M, Simmons M, Skandamis P, Snary E, Speybroeck N, Kuile BT, Threlfall J, Wahlstrom H, Takkinen J, Wagner M, Arcella D, Da Silva Felicio MT, Georgiadis M, Messens W, Lindqvist R. 2018. Listeria monocytogenes contamination of ready-to-eat foods and the risk for human health in the EU. EFSA Journal, 16 (1): 5134. DOI: $10.2903 /$ j.efsa.2018.5134.

Rivas FP, Castro MP, Vallejo M, Marguet E, Campos CA. 2012. Antibacterial potential of Enterococcus faecium strains isolated from ewes' milk and cheese. LWT- Food Sci Technol., 46: 428-436. DOI: 10.1016/j.lwt.2011.12.005.

Silva VP, Pereira OG, Leandro ES, Da Silva TC, Ribeiro KG, Mantovani HC. 2016. Effects of lactic acid bacteria with bacteriocinogenic potential on the fermentation profile and chemical composition of alfalfa silage in tropical conditions. J Dairy Sci., 99 (3): 1895-1902. DOI:10.3168/jds.20159792.

Sonsa-Ard N, Rodtong S, Chikindas ML, Yongsawatdigu J. 2015. Characterization of bacteriocin produced by Enterococcus faecium CN25 isolated from traditionally Thai fermented fish roe. Food Control, 54:308-316. DOI: 10.1016 /j.foodcont.2015.02.010.

Şanlıbaba P, Uymaz Tezel B, Çakmak GA. 2018a. Prevalence and Antibiotic Resistance of Listeria monocytogenes Isolated from Ready-to-Eat Foods in Turkey. J of Food Qual., DOI: $10.1155 / 2018 / 7693782$.

Şanlıbaba P, Uymaz Tezel B, Çakmak GA. 2108b. Detection of Listeria spp. in raw milk and dairy products retailed in Ankara. Gida, 43 (2): 273, 282. DOI: 10.15237 /gida.GD17107.

Şanlibaba P, Uymaz Tezel B. 2018c. Prevalence and Characterization of Listeria Species from Raw Milk and Dairy Products from Çanakkale Province. TURJAF, 6 (1): 61-64. DOI: 10.24925/turjaf.v6i1.61-64.1641.

Tagg JR, Mcgiven AR. 1971. Assay Systems for Bacteriocins. Appl Environ Microbiol., 21: 943-947.

Uymaz B, Şimşek Ö, Akkoç N, Ataoğlu H, Akçelik M. 2009. In vitro characterization of probiotic properties of Pediococcus pentosaceus BH105 isolated from human faeces. Ann Microbiol., 59 (3): 485-491.

van Belkum MJ, Hayema BJ, Geis A, Kok J, Venema G. 1989. Cloning of two bacteriocin genes from a lactococcal bacteriocin plasmid. Appl Environ Microbiol., 55: 11871191.

Yang E, Fan L, Jiang Y., Doucette C, Fillmore S. 2012. Antimicrobial activity of bacteriocin-producing lactic acid bacteria isolated from cheeses and yogurts. AMB Express, 2 (1): 48. DOI:10.1186/2191-0855-2-48. 